\begin{tabular}{|l|l|}
\hline $\begin{array}{l}\text { Instituto de } \\
\text { Geriatria e Gerontologia }\end{array}$ & $\begin{array}{l}\text { Pan American Journal of Aging Research } \\
\text { PAJAR, Porto Alegre, v. 8, p. 1-4, jan.-dez. } 2020 \\
\text { ISSN-L: 2357-9641 }\end{array}$ \\
\hline denttp://dx.doi.org/10.15448/2357-9641.2020.1.37125 & \\
\cline { 1 - 2 } &
\end{tabular}

EDITORIAL

\title{
Epigenomic profile and biological age
}

\author{
Perfil epigenômico e idade biológica \\ Perfil epigenómico y edad biológica
}

\section{Denise Cantarelli}

Machado ${ }^{1}$

orcid.org/0000-0002-9371-5886

dcm@pucrs.br

Received on: Feb. $03^{\text {rd }}, 2020$.

Approved on: Feb. $17^{\text {th }}, 2020$.

Published on: Aug. 03rd, 2020.
Abstract: Man ages at a constant chronological rate while their biological aging rate is extremely variable. Interventions to improve, or to slow the rate of biological aging are the subject of several research. The broad spectrum of molecules and its intricate role from the biological point of view and its relation with environmental factors are being investigated. Recently, researchers have been putting its efforts to understand the epigenetic mechanisms and how it can interfere with alterations in gene expression that leads to predisposition and, or pathological outcome. Some of these investigations have shed light about how one can determine the biological age from a simple blood sample, just by detecting the epigenetic alterations on only three CpGs sites with a reasonable certainty. Also, the enzymes inhibitors that can interfere with methylation and demethylation were effective to reverse the epigenetic mechanisms. Other studies have shown how the environmental changes since from early life can affect these alterations on the epigenome. Taking all together, some biomolecular markers are already available to determine the genetic background of an individual and this information can be used to guide the lifestyle in order to prevent some future diseases development and/or improve the quality of later life.

Keywords: biological aging, chronological aging, epigenome, methylation, molecular marker.

Resumo: O homem envelhece a uma taxa cronológica constante, enquanto a taxa de envelhecimento biológico é extremamente variável. Intervenções para melhorar ou reduzir a taxa de envelhecimento biológico tem sido objeto de várias pesquisas. O amplo espectro de moléculas e suas complexas funções biológicas, bem como sua relação com os fatores ambientais tem sido investigado e os pesquisadores tem se dedicado a compreensão dos mecanismos epigenéticos e como podem interferir nas alterações de expressão gênica que leva a predisposição ou a um desfecho patológico. Algumas dessas investigações identificou como podemos determinar a idade biológica a partir de uma simples amostra de sangue, por meio da detecção de alterações epigenéticas em somente três ilhas CpGs com ampla margem de segurança. Igualmente, os inibidores das enzimas que atuam nos processos de metilação e desmetilação foram eficazes na reversão dos mecanismos epigenéticos. Outros estudos mostraram como as alterações ambientais, desde o início da vida, podem afetar o epigenome. Resumindo, alguns marcadores moleculares para determinar o perfil genético de um indivíduo já estão disponiveis e esta informação poderá ser usada para orientar o estilo de vida visando a prevenção e/ou desenvolvimento de futuras doenças melhorando a qualidade de vida do ser humano na idade mais avançada. Palavras-chave: envelhecimento biológico; envelhecimento cronológico; epigenome;, metilação; marcador molecular.

Resumen: El hombre envejece a una tasa cronológica constante, mientras que su tasa de envejecimiento biológico es extremadamente variable. Las intervenciones para mejorar o disminuir la tasa de envejecimiento biológico son objeto de várias investigaciones. Se está investigando el amplio espectro de moléculas y su intrincado papel desde el punto de vista biológico y su relación con los factores ambientales. Recientemente, los investigadores han estado poniendo sus esfuerzos 
para comprender los mecanismos epigenéticos y cómo puede interferir con las alteraciones en la expresión génica que conducen a la predisposición y/o al resultado patológico. Algunas de estas investigaciones han arrojado luz sobre cómo se puede determinar la edad biológica a partir de una muestra de sangre simple, simplemente detectando las alteraciones epigenéticas en solo tres sitios CpG con una certeza razonable. Además, los inhibidores de enzimas que pueden interferir con la metilación y la desmetilación fueron efectivos para revertir los mecanismos epigenéticos. Otros estudios han demostrado cómo los cambios ambientales desde la vida temprana pueden afectar estas alteraciones en el epigenoma. En conjunto, algunos marcadores biomoleculares ya están disponibles para determinar el origen genético de un individuo y esta información se puede utilizar para guiar el estilo de vida a fin de prevenir el desarrollo de enfermedades futuras y / o mejorar la calidad de la vida posterior.

Palabras clave: envejecimiento biológico; envejecimiento cronológico; epigenome; metilación; marcador molecular.

One of our biggest fears during aging is losing the cognitive capability and, consequently, our independence. Man ages at a constant chronological rate while their biological aging rate is extremely variable. The gerontologists have distinguished between chronological and biological aging, where the latter are directly dependent of its genetic background, environmental, and lifestyle that will affect the rate of aging since early development.

The understanding of how, all the distinct organisms on earth, age at the molecular level have being the aim of an unprecedented number of research that range from plants, nematodes, flies, rodents, non-human primates and humans. Also, interventions to improve, or to slow the rate of biological aging are the subject of several research in vitro and in vivo, up to clinical trials. However, spite of the great amount of date obtained from these studies, there are a lot of questions still unanswered.

Here we will highlight some of the investigations that fond some biomarkers that can help to disclose the biological aging instead of our chronological aging. That can explain, at least in part, why we found a wide range of longevity whiting humans. For that, one has to consider the broad spectrum of molecules and its intricate role from the biological point of view and its relation with environmental factors.
Recently, researchers have been putting its efforts to understand the epigenetic mechanisms and how it can interfere with alterations in gene expression that leads to predisposition and, or pathological outcome. Briefly, alterations on gene expression can be achieved by changes on the genomic DNA or by epigenetic mechanisms, and is named epigenome. The genomic DNA are well known by having a combination of four nucleotides, adenine, thymine, cytosine and guanine, that we have received from our parents.

The epigenome are a group of molecules and interactions that can be reversed according to the biomolecular needs. It is composed of the chromatin, with its modifications, as well as some covalent binding of methyl groups at the cytosine residues on CpG sequences, called methylation (1). More recently, other regulatory molecules were identifying, knowns as microRNAs, or small non coding RNAs, that can regulate gene expression by interfering with the messenger RNA (mRNA) by blocking its translation, silence the chromatin, or even degrade the mRNA. One microRNA can interfere with several different genes, and various microRNAs can target only one gene (2).

The epigenome are composed by the chromatin, around a group of proteins named histones. The histones $\mathrm{H}_{1}, \mathrm{H}_{2} \mathrm{~A}, \mathrm{H}_{2} \mathrm{~B}, \mathrm{H}_{3}$ and $\mathrm{H}_{4}$ (3) form an octamer made by a $\mathrm{H}_{3}-\mathrm{H}_{4}$ tetramer with $\mathrm{H}_{2} \mathrm{~A}-\mathrm{H}_{2} \mathrm{~B}$ dimers, one in each side of the tetramer. The $\mathrm{N}$-terminal tail of the histones can be modified by methylation, phosphorylation, acetylation, sumoylation, and ubiquitination (4-7). These modifications can define the DNA accessibility to transcription and consequently, a number of drugs are being developed to inhibit these alterations to use as modulator for therapy with a certain degree of specificity in clinical trial.

The histone deacetylation is made by and enzyme named histone deacetylases (HDACs) and the acetylation is made by histone acetylases (HATs). Drugs that interfere with one of those two enzymes have been used for in vitro studies, as well as in vivo, to treat cancer, including solid tumors, and has potential to be used to treat mental pathologies, within others (8-10). Some examples 
are trichostatin A (TSA), suberoylanilide hydroxamic acid (SAHA), sodium butyrate and valproic acid, used as mood stabilizer and antiepileptic drugs, respectively. Since all histone deacetylases inhibitors (HDACis) can block some or all classes of HDACs, it will affect gene expression over all the genome (1). However, some investigators have shown that only some transcripts can be activated or suppressed by HDACis.

In animal models, it was show that the chromatin acetylation is involved with memory formation, and together with the well stablished role of valproic acid as a mood stabilizer and antiepileptic drug, it was also considered a HDAC inhibitor. HDCAis can not only improve memory but also were able to promote dendritic sprouting in a mouse model of neurodegeneration disease (11). Other diseases, such as autoimmune and proinflamatory diseases have being investigated, as well as diabetes type 2 (12-14).

Another strategy to modulate the epigenome are the use of inhibitor of the histone methyltransferase (HMTase), that is an enzyme that add the methyl group to cytosine beside a guanine (CpGs) residues on the genomic DNA. In addition, the histone demethylases are also target for investigation since the overall methylation is a consequence of a balance between methylation and demethylation, and one well known antidepressive drug, tranylcypromine, is a histone demethylase (15). The genome methylation pattern differs within different tissues and, therefore, is gene and tissue specific (16-18). The main impact of a methylation is the gene silencing, that block protein expression. This can be achieved by the binding to transcription factors, or by attracting methylated DNA binding proteins (MBDs). The methylation, itself, is catalyzed by the DNA methyl transferases (DNMTs) just after replication. The methylation is a reversible reaction that maintain the genomic balance and the epigenetic profile. Inhibitors of DNMTs, procainamida, hydralazine and valproic acid, have been used to treat some malignancies in clinical trials or to treat other diseases. Since each enzyme can have distinct isoforms, some with specific actions, there is a need to better understand the role of each isotypic actors of epigenome (HDACs, HMTases, DNMTs and demethylases) to develop isotypic specific inhibitor, to overcome global genome epigenetic modification that can cause the unbalance of gene expression (1).

An interesting study made by Weaver and colleagues (2004), have shown that the rats maternal behavior can stablish the offspring epigenome, in the brain, in the first week after birth. They found that the glucocorticoid receptor gene expression was modulate by maternal care with its offspring, producing stable alterations on DNA methylation and chromatin structure, although they did not know the exact molecular mechanism behind this phenomenon (19).

The relation of epigenome and aging seems to be more evident after the work of Weidner et al. 2014 where they investigate the epigenetic signature of individuals with age ranging from o to 78 years old, from four different studies. From $27.578 \mathrm{CpGs}$ sites they found that 58 were hypomethylated while 44 hypermethylated. From these data, they develop a multivariate linear model to predict donors age based on these 102 age-related CpG (AR-CpG) sites, and further evaluate the same parameters using mesenchymal stromal cell line with early and old passage (MSCs), induced pluripotent stem cells (iPSCs), embryonic stem cells (ESCs). They also compare the predicted biological age with the chronological age and found reliable they algorithm with a mean absolute deviation (MAD) of only 3.34 years. Moreover, the iPSCs from centenary donors reset telomere length, gene expression profile and other physiological features from young cells, that means, the methylation can be reversed and also, another strategy to hold aging, which is the telomere shortening and telomerase activity are restored and were indistinguishable from ESCs. They look for subsets of AR-CpGs and pointed to three CpGs sites that shown a clear age association (MAD 5 years), that was validated on 69 blood samples. They conclude that those three CpGs sites are useful to predict human age from blood samples and 
that could be useful in the clinical point of view to assess the individual aging profile that can guide the geriatric health and the lifestyle design. Aging is a continuous deviation of epigenetic born profile, that are cell and tissue specific in humans (20).

\section{REFERENCES}

1. SzyfM. Epigenetics, DNA methylation, and chromatin modifying drugs. Ann. Rev. Pharmacol. Toxicol. 2009; 49: 243-63. https://doi.org/10.1146/annurev-pharmtox-061008-103102.

2. Bergman A, Lane ME. HIDden targets of microRNAs for growth control. Trends Biochem. Sci. 2003; 28:46163. https://doi.org/10.1016/S0968-0004(03)00175-0.

3. Finch JT, Lutter LC, Rhodes D, Brown RS, Rushton B, Levitt M, Klug A. Structure of nucleosome core particles of chromatin. Nature 1977; 269: 29-36. https://doi. org/10.1038/269029a0.

4. Jenuwein T. Re-SET-ting heterochromatin by histone methyltransferases. Trends Cell Biol. 2001; 11: 266-73. https://doi.org/10.1016/S0962-8924(01)02001-3.

5. Wade PA, Pruss D, Wolfe AP. Histone acetylation: chromatins in action. Trends Biochem. Sci. 1997; 22:12832. https://doi.org/10.1016/S0968-0004(97)01016-5.

6. Shiio Y, Eisenman RN. Histone sumoylation is associated with transcriptional repression. Proc. Natl. Acad. Sci. USA, 2003; 100:13225-30. https://doi.org/10.1073/ pnas.1735528100.

7. Shilatifard A. Chromatin modifications by methylation and ubiquitination: implications in the regulation of gene expression. Annu Rev. Biochem. 2006; 75: 243-69. https:// doi.org/10.1146/annurev.biochem.75.103004.142422.

8. Bolden JE, Peart MJ, Johnstone RW. Anticancer activities of histone deacetylase inhibitors. Nat. Rev. Drug Discov. 2006; 5: 769-84. https://doi.org/10.1038/hrd2133.

9. Rasheed WK, Johnstone RW, Prince HM. Histone deacetylase inhibitors in cancer therapy. Expert Opin. Investig. Drigs, 2007; 16: 659-78. https://doi. org/10.1517/13543784.16.5.659.

10. Simonini, MV et al. The benzamide MS-275 is a potent, long-lasting brain region-selective inhibitor of histone deacetylases. Proc. Natl. Acad. Sci. USA, 2006; 103: 1587-92. https://doi.org/10.1073/pnas. 0510341103.

11. Fischer A, Sananbenesi F, Wang X, Dobbin M. Tsai $\mathrm{LH}$. Recovery of learning and memory is associated with chromatin remodeling. Nature, 2007; 447: 178-82. https://doi.org/10.1038/nature05772.

12. Tao $\mathrm{R}$ et al. Deacetylase inhibition promotes the generations and function of regulatory T cells. Nat. Med. 2007; 13: 1299-307. https://doi.org/10.1038/nm1652.

13. Johnson J, Pahuja A, Graham M, Hering B, Hancock W W, Bansal-Pakala P. Effects of histone deacetylase inhibitor SAHA on effector and FOXP3+regulatory T cells in rhesus macaques. Transpl. Proc. 2008; 40: 459-61. https://doi.org/10.1016/j.transproceed.2008.01.039.
14. McGee SL, Hargreaves M. Exercise and skeletal muscle glucose transporter 4 expression: molecular mechanisms. Clin. Exp. Pharmacol. Physiol. 2008; 33: 39599. https://doi.org/10.1111/j.1440-1681.2006.04362.x.

15. Lee MG et al. Histone $\mathrm{H} 3$ lysine 4 demethylation is a target of nonselective antidepressive medications. Chem. Biol. 2006; 13: 563-67. https://doi.org/10.1016/j. chembiol.2006.05.004.

16. Razin A, Riggs AD. DNA methylation and gene function. Science, 1980; 210: 604-10. https://doi.org/10.1126/ science.6254144.

17. Razin A, Cedar H. Distribution of 5-methylcytosine in chromatin. Proc. Natl. Acad. Sci. USA 1977; 74: 2725-28. https://doi.org/10.1073/pnas.74.7.2725.

18. D'Alessio AC, Szyf M. Epigenetic tete-a-tete: the bilateral relationship between chromatin modifications and DNA methylation. Biochem. Cell Biol. 2006; 84: 46376. https://doi.org/10.1139/006-09o.

19. Weaver, ICG et al. Epigenetic programming by maternal behavior. Nat. Neurosci. 2004; 7:847-54. https:// doi.org/10.1038/nn1276.

20. Weidner Cl, Lin Q, Koch CM, Eisele L, Beier F, Ziegler P, Bauerschlag DO, Jöckel KH, Erbel R, Mühleisen TW, Zenke M, Brümmendorf TH, Wagner W. Aging of blood can be tracked by DNA methylation changes at just three CpG sites. Genome Biol. 2014; 15(2): R24. https:// doi.org/10.1186/gb-2014-15-2-r24.

\section{Denise Cantarelli Machado}

Full professor at Medical School, Coordinator of Pré-clinical research at Bralns (Brain Institute of Rio Grande do Sul), Coordinator of Graduation course on Biomedical Gerontology, Coordinator of Research Integrity Office. Pontifical Catholic University of Rio Grande do Sul (PUCRS), Porto Alegre, Brazil.

\section{Mailing address}

Denise Cantarelli Machado

Pontificia Universidade Católica do Rio Grande do Sul Av. Ipiranga, 6690

Prédio 63, Instituto do Cérebro do Rio Grande do Sul 